\title{
Kemampuan Penyelesaian Soal Open Ended Berbasis Problem Solving Matematika Siswa Kelas VII SMP Muhammadiyah Aimas Kabupaten Sorong
}

\author{
Syamsulrizal $^{1}$, Nia Sugiarti Aruan ${ }^{2}$ \\ Program Studi Pendidikan Matematika Fakultas Keguruan dan Ilmu Pendidikan \\ Universitas Pendidikan Muhammadiyah Sorong \\ syamsulrizal05@gmail.com
}

\begin{abstract}
Abstrak: Penelitian ini bertujuan untuk mengetahui kemampuan siswa dalam menyelesaikan soal open-ended berbasis problem solving. Motode penelitian yang digunakan yaitu deskriptif kulitatif dengan subjek siswa kelas VII SMP Muhammadiyah Aimas Kabupaten Sorong yang di kelompokkan berdasarkan tingkat kemampuan yaitu dua orang siswa berkemampuan rendah, dua orang siswa berkemampuan sedang dan dua orang siswa berkemampuan tinggi. Hasil penelitian menunjukan bahwa Tahap memahami masalah untuk kelomopok kemampuan Tinggi termasuk kategori baik mencapai 100\%, kategori kelompok kemampuan Sedang termasuk kategori baik mencapai $75 \%$, dan kelompok kemampuan Rendah juga termasuk dalam kategori baik mencapai $75 \%$. Tahap menyusun rencana pemecahan masalah untuk kelomopok kemampuan Tinggi termasuk kategori baik 100\%, kategori kelompok kemampuan Sedang termasuk kategori cukup 50\%, dan kelompok kemampuan Rendah juga termasuk dalam kategori cukup 58,3\%. Tahap melaksanakan rencana pemecahan masalah kelomopok kemampuan Tinggi $(\mathrm{T} 1, \mathrm{~T} 2)$ termasuk kategori baik $100 \%$, kategori kelompok kemampuan Sedang termasuk kategori cukup 54,2\%, dan kelompok kemampuan Rendah juga termasuk dalam kategori cukup 58,3\%. Tahap mengecek kembali. Kategori kelomopok kemampuan Tinggi dalam mengecek kembali termasuk kategori baik 100\%, kategori kelompok kemampuan Sedang (S1, S2) termasuk kategori kurang 33,3\%, dan kelompok kemampuan Rendah juga termasuk dalam kategori kurang 33,3\%.
\end{abstract}

Kata Kunci: Open ended, problem solving. 


\section{Pendahuluan}

Negara yang maju tentunya memiliki masyarakat yang memiliki intelektual yang tinggi, dan masyarakat yang intelek dihasilkan dari sistem pendidikan yang berpijak pada pemecahan masalah. Hal tersebut diungkapkan oleh Organisation for Economic Cooperation an Development (OECD) (2015) yang menyatakan bahwa pemecahan masalah harus diperhatikan dalam sistem pendidikan. Dalam sistem pendidikan di Indonesia pembelajaran matematika di SD/SMP diarahkan untuk mendorong peserta didik mencari tahu dari berbagai sumber, mampu merumuskan masalah bukan hanya menyelesaikan masalah sederhana dalam kehidupan sehari-hari.

Pemikiran tersebut sejalan dengan sistem pendidikan di Singapura khususnya pada mata pelajaran matematika.Pendidikan Singapura menjadikan problem solving menjadi pusat pembelajaran.Tidak hanya itu, sistem tersebut juga sudah berjalan sejak tahun 2007 sehingga tidak heran kemampuan berpikir matematika siswa di Singapura menempati peringkat pertama dari 79 negara menurut hasil studi Program for International Student Assessment (PISA) 2015.

Pentingnya kemampuan pemecahan masalah matematika sebagaimana dikemukakan Branca (Nurman, 2008) sebagai berikut: (a) pemecahan masalah merupakan tujuan umum pengajaran matematika, (b) pemecahan masalah yang meliputi metode, prosedur, dan strategi merupakan proses inti dan utama dalam kurikulum matematika, dan (c) pemecahan masalah merupakan kemampuan dasar dalam belajar matematika. Di lihat dari hasil studi PISA pada tahun 2015 yang menyatakan bahwa kemampuan literasi siswa Indonesia hanya menempati peringkat 69 dari 76 negara. Sementara itu rata-rata skor internasional kemampuan literasi matematika siswa adalah 500 (level 3), sedangkanrata-rata skor literasi Indonesia hanya 375 (level1).

Soal matematika dapat menjadi masalah matematika jika siswa tidak mempunyai gambaran untuk menyelesaikan permasalahan, tetapi siswa tersebut berkeinginan untuk menyelesaikan masalah matematika tersebut (Widjayanti, 2009). Soal matematika yang diberikan untuk mendorong kemampuan berfikir siswa yaitu soal terbuka (open ended). Kemampuan berfikir siswa dapat diidentifikasi dengan pemberian soal open ended. Soal terbuka (open ended) adalah salah satu cara penyajian berbagai macam pendekatan yang mungkin untuk menyelesaikan soal atau adanya berbagai macam kemungkinan jawaban yang memiliki lebih dari satu jawaban atau cara penyelesaian yang benar. Soal open ended ini merupakan soal yang dapat digunakan untuk mengukur tingkat kemampuan berpikir siswa (Foong, 2009).

Ide tentang langkah-langkah pemecahan masalah dirumuskan oleh beberapa ahli. Sukayasa (2012) menuliskan perbandingan langkah-langkah dalam pemecahan masalah menurut beberapa ahli yang disajikan dalam table 1 .

Tabel 1. Perbandingan Langkah-langkah Dalam Pemecahan Masalah Fase-fase pemecahan masalah

Krulick dan Rudnick (1995) $\quad$ Polya (1993) John Dewey dalam Swadener
(1985)

1. Membaca dan memikirkan (read 1. Memahami masalah and thingking) (understanding problem)

1. Pengenalan (recognition)

2. Mengeksplorasi dan merencanakan 2. Membuat rencana (explore and plan) penyelesaian (devising a plan)

2. Pendefinisian (definition) 
3. Memilih suatu strategi (select $a$ 3. Melakukan strategy).

4. Menemukan suatu jawaban (find an answer)

5. Meninjau kembali dan mendiskusikan (reflect and extend)
3. Perumusan (formulation)

Rencana penyelesaian

(carrying a plan)

4. Mengecek kembali hasilnya

(looking back)
4. Mencobakan (test)

5. Evaluasi (evaluation)

Table 1 di atas menunjukan bahwa langkah-langakah penyelsaian masalah Polya lebih sederhana diamana empat tahap tersebut dapat dilakukan agar siswa lebih terarah dalam menyelesaikan masalah matematika.

Sutrisno, et al (2013) menyajikan indikator yang dapat dijadikan pedoman dalam pengukuran kemampuan pemecahan masalah (problem solving) matematika siswa dengan penjabaran pada tabel 2 berikut:

Tabel 2. Indikator Pemecahan Masalah Matematika

\begin{tabular}{|c|c|c|c|}
\hline Tahap & $\begin{array}{c}\text { Pemecahan } \\
\text { Masalah }\end{array}$ & Poin-poin & Indikator \\
\hline 1 & $\begin{array}{l}\text { Memahami } \\
\text { masalah }\end{array}$ & $\begin{array}{l}\text { Kemampuan siswa dalam menerima } \\
\text { informasi yang ada pada soal, kemampuan } \\
\text { siswadalam memilih informasi penting } \\
\text { dan tidak penting. }\end{array}$ & $\begin{array}{l}\text { Siswa dapat menentukan syarat cukup } \\
\text { (hal-hal yang diketahui) dan syarat perlu } \\
\text { (hal-hal yang ditanyakan), siswa dapat } \\
\text { menentukan apakah syarat cukup } \\
\text { tersebut sudah memenuhi untuk } \\
\text { menjawab syarat perlu. }\end{array}$ \\
\hline 2 & $\begin{array}{l}\text { Menyusun } \\
\text { rencana } \\
\text { pemecahan } \\
\text { masalah }\end{array}$ & $\begin{array}{l}\text { Kemampuan siswa dalam mengetahui } \\
\text { kaitan antara informasi yang ada dan } \\
\text { informasi yang ditanya, kemampuan } \\
\text { siswa dalam menentukan syarat lain di } \\
\text { luar syarat yang diketahui pada soal untuk } \\
\text { menyelesaikan masalah; jika ada, } \\
\text { kemampuan siswa dalam memeriksa } \\
\text { apakah semua informasi penting telah } \\
\text { digunakan, kemampuan siswa dalam } \\
\text { merencanakan pemecahan masalah. }\end{array}$ & $\begin{array}{l}\text { Siswa dapat menentukan keterkaitan } \\
\text { antara informasi yang ada pada soal, } \\
\text { siswa dapat menentukan syarat lain yang } \\
\text { tidak diketahui pada soal tersebut seperti } \\
\text { rumus atau informasi lainnya; jika ada, } \\
\text { siswa dapat menggunakan semua } \\
\text { informasi penting pada soal, siswa dapat } \\
\text { merencanakan penyelesaian atau } \\
\text { pemecahan masalah. }\end{array}$ \\
\hline 3 & $\begin{array}{l}\text { Melaksanakan } \\
\text { rencana } \\
\text { pemecahan }\end{array}$ & $\begin{array}{l}\text { Kemampuan siswa dalam membuat } \\
\text { langkah-langkah pemecahan masalah } \\
\text { secara benar, kemampuan siswa dalam } \\
\text { memeriksa setiap langkah pemecahan. }\end{array}$ & $\begin{array}{l}\text { Siswa dapat menggunakan langkah- } \\
\text { langkah secara teratur, siswa terampil } \\
\text { dalam algoritma dan ketepatan } \\
\text { menjawab soal. }\end{array}$ \\
\hline 4 & $\begin{array}{l}\text { Memeriksa } \\
\text { kembali }\end{array}$ & $\begin{array}{l}\text { Kemampuan siswa dalam menyakini } \\
\text { kebenaran dari solusi masalah tersebut } \\
\text { (dengan melihat kelemahan dari solusi } \\
\text { yang didapatkan, seperti langkah-langkah } \\
\text { yang tidak benar). Kemampuan siswa } \\
\text { dalam menerapkan metode penyelesaian } \\
\text { yang telah dilakukan terhadap masalah } \\
\text { lainnya. }\end{array}$ & $\begin{array}{l}\text { Siswa dapat meyakini kebenaran dari } \\
\text { solusi masalah tersebut (dengan melihat } \\
\text { kelemahan dari solusi yang didapatkan, } \\
\text { seperti langkah-langkah yang tidak } \\
\text { benar), siswa dapat menentukan } \\
\text { keterkaitan antara metode atau } \\
\text { pemecahan masalah yang digunakan } \\
\text { untuk diterapkan pada masalah lainnya. }\end{array}$ \\
\hline
\end{tabular}


Tabel 3. Indikator kemampuan pemecahan masalah berbentuk Masalah Tahapan Polya

\begin{tabular}{|c|c|c|c|c|}
\hline \multicolumn{2}{|r|}{$\begin{array}{l}\text { Tahap Pemecahan } \\
\text { Masalah oleh Polya }\end{array}$} & Kategori & Skor & Keterangan \\
\hline \multirow{3}{*}{\multicolumn{2}{|c|}{$\begin{array}{l}\text { Memahami } \\
\text { Masalah }\end{array}$}} & Baik & 3 & $\begin{array}{l}\text { Siswa dapat menyebutkan dengan baik informasi yang ada pada } \\
\text { soal dan dapat menyebutkan apa yang diketahui, ditanya dalam } \\
\text { soal open ended berbasis problem solving. }\end{array}$ \\
\hline & & Cukup & 2 & $\begin{array}{l}\text { Siswa cukup dapat menyebutkan informasi yang ada pada soal dan } \\
\text { cukup dapat menyebutkan apa yang diketahui, ditanya dalam soal } \\
\text { open ended berbasis problem solving. }\end{array}$ \\
\hline & & Kurang & 1 & $\begin{array}{l}\text { Siswa dapat menyebutkan salah satu informasi dengan benar yang } \\
\text { ada pada soal seperti diketahui atau ditanya dalam soal open } \\
\text { ended berbasis problem solving }\end{array}$ \\
\hline \multirow{3}{*}{\multicolumn{2}{|c|}{$\begin{array}{l}\text { 2. Menyusun } \\
\text { Penyelesaian }\end{array}$}} & Baik & 3 & $\begin{array}{l}\text { Siswa menyusun rencana pemecahan masalah dan rencana } \\
\text { tersebut dapat membantunya dalam memecahkan masalah } \\
\text { matematika berbentuk open ended dengan tepat }\end{array}$ \\
\hline & & Cukup & 2 & $\begin{array}{l}\text { Siswa menyusun rencana pemecahan masalah dan rencar } \\
\text { tersebutcukup dapat membantunya dalam memecahkan masala } \\
\text { matematika berbentuk soal open ended. }\end{array}$ \\
\hline & & Kurang & 1 & $\begin{array}{l}\text { Siswa tidak dapat menentukan langkah-langkah penyelesaian } \\
\text { untuk menjawab soal open ended. }\end{array}$ \\
\hline \multirow{3}{*}{\multicolumn{2}{|c|}{$\begin{array}{l}\text { 3. Melaksanakan } \\
\text { Rencana } \\
\text { Penyelesaian }\end{array}$}} & Baik & 3 & $\begin{array}{l}\text { Siswa dapat menyelesaikan soal sesuai langkah-langkah } \\
\text { penyelesaian secara runtut dan menentukan hasil akhir dengan } \\
\text { benar. }\end{array}$ \\
\hline & & Cukup & 2 & $\begin{array}{l}\text { Terdapat langkah penyelesaian soal yang sesuai dengan rencana } \\
\text { penyelesaian soal, namun siswa tidak dapat menentukan hasil } \\
\text { akhir dengan benar. }\end{array}$ \\
\hline & & Kurang & 1 & $\begin{array}{l}\text { Siswa tidak dapat menyelesaikan soal sesuai langkah-langkah } \\
\text { penyelesaian dan tidak dapat menentukan hasil akhir dengan } \\
\text { benar. }\end{array}$ \\
\hline \multirow{3}{*}{\multicolumn{2}{|c|}{$\begin{array}{l}\text { 4. Memeriksa } \\
\text { Kembali }\end{array}$}} & Baik & 3 & $\begin{array}{l}\text { Siswa memeriksa kembali langkah-langkah pemecahan masalah } \\
\text { matematikayang berbentuk soal open ended secara menyeluruh. }\end{array}$ \\
\hline & & Cukup & 2 & $\begin{array}{l}\text { Siswa memeriksa kembali langkah pemecahan masalah } \\
\text { matematika berbentuk soalopen ended yang ia gunakan namun } \\
\text { hanya sebagian. }\end{array}$ \\
\hline & & Kurang & 1 & $\begin{array}{l}\text { Siswa tidak memeriksa kembali langkah pemecahan masalah } \\
\text { matematika berbentuk soalopen ended yang ia gunakan. }\end{array}$ \\
\hline
\end{tabular}

Menurut Heddens dan Speer (dalam Mustikasari, 2010), mengungkapkan bahwa dengan pemberian soal terbuka, dapat memberi rangsangan kepada siswa untuk meningkatkan cara berpikirnya, siswa memiliki kebebasan untuk mengekspresikan hasil eksplorasi daya nalar dan analisanya secara aktif dalam upaya menyelesaikan suatu permasalahan.

Menurut Becker \& Shimada (Takahashi, 2005), beberapa keunggulan berkenaan dengan pemberian soal open ended dalam matematika adalah: (1) Siswa mengambil bagian lebih aktif dalam pembelajaran, dan lebih sering menyatakan ide-ide mereka. (2) Siswa mempunyai lebih banyak peluang menggunakan pengetahuan dan keterampilan matematis mereka. (3) Siswa dengan kemampuan rendah bisa memberikan reaksi terhadap masalah dengan beberapa cara signifikan dari milik mereka sendiri. (4) Mendorong Siswa untuk memberikan bukti. (5) Siswa mempunyai pengalaman yang kaya dan senang atas penemuan mereka dan menerima persetujuan temannya. 


\section{Metode Penelitian}

Penelitian ini bertujuan untuk mendeskripsikan kemampuan penyelesaian soal open ended matematika berbasis problem solving dengan menggunakan langkah-langkah tahapan Polya. Jenis penelitian yaitu digunakan penelitian kualitatif deskriptif dengan subjek penelitian yaitu 2 siswa berkemampuan Tinggi, 2 siswa berkemampuan sedang, dan 2 siswa berkemampuan rendah dengan cara purposive sampling yang berdasarkan tujuan yang hendak dicapai yaitu mengetahui kemampuan pemecahan masalah peserta didik ditinjau dari langkah-langkah polya. Teknik dan istrumen pengumpulan data yang digunakan yaitu tes yang di susun dalam bentuk soal uraian selanjutnya dengan menggunakan wawancara tidak terstruktur dengan menggunakan alat perekam yang kemudian di susun dalam bentuk transkip wawancara. Berikut digambarkan alur dalam rancangan penelitian.

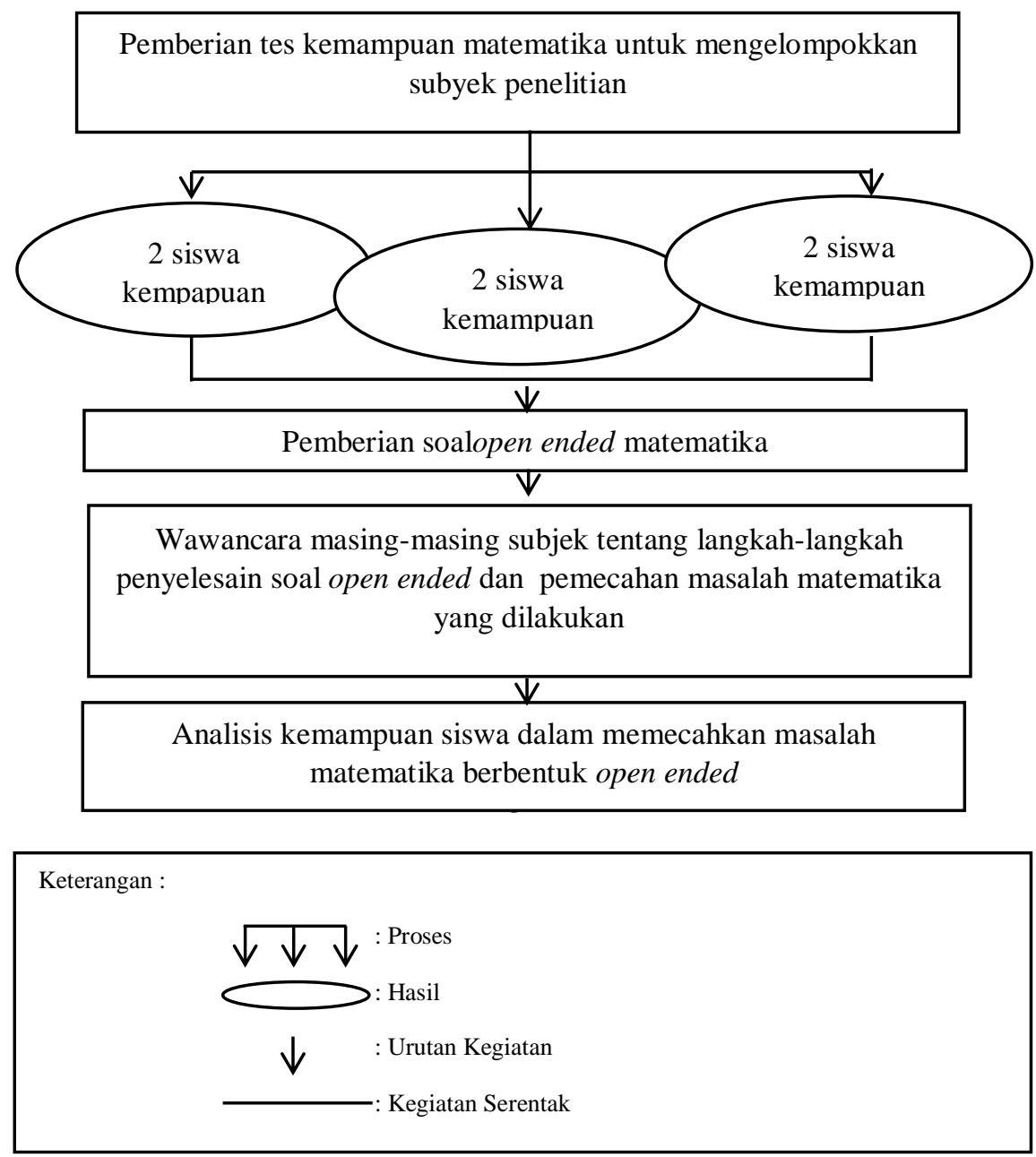

\section{Hasil dan Pembahasan}

Data penelitian ini dianalisis melalui petikan jawaban subjek dengan mengacu pada kode petikan jawaban subjek dalam transkrip wawancara.Siswa-siswa yang terpilih menjadi subjek dikodekan dengan huruf kapital yang terdiri dari siswa berkemampuan Tinggi (T1, T2) siswa berkemampuan Sedang ( $\mathrm{S} 1, \mathrm{~S} 2)$, dan siswa berkemampuan Rendah (R1,R2), pengkodean pada soal dengan menggunakan angka $(1,2,3,4)$, selanjutnya pengkodean pada transkrip wawancara menggunakan 3 digit angka yang diawali dengan $(001,002,003$, dst...). Penskoran analisis data pada tabel dibawah ini disimbolkan dengan kategori kurang (1), kategori cukup (2), dan kategori baik (3). 


\section{a. Siswa Berkemampuan Tinggi}

Siswa berkemampuan tinggi dalam penelitian ini dihasilkan berdasarkan nilai yang diperoleh dengan mengacu pada hasil tes kemampuan matematika yang memperoleh nilai (80 $<x \leq 100)$. Berikut ini adalah hasil proses penyelesaian soal opend ended dengan menggunakan langkah Polya pada siswa yang berkemampuan Tinggi.

Tabel 4. Deskripsi langkah siswa berkemampuan Tinggi berdasarkan langkah Polya

\begin{tabular}{cccccccccccc}
\hline $\begin{array}{c}\text { Langkah } \\
\text { Polya }\end{array}$ & $\mathbf{1}$ & $\mathbf{2}$ & $\mathbf{9 I}$ & $\mathbf{3}$ & $\mathbf{4}$ & $\mathbf{1}$ & $\mathbf{2}$ & $\mathbf{3}$ & $\mathbf{4}$ & $\begin{array}{c}\text { Skor } \\
\text { Polya }\end{array}$ & $\begin{array}{c}\text { \% } \\
\text { tahapan }\end{array}$ \\
1 & 3 & 3 & 3 & 3 & 3 & 3 & 3 & 3 & 3 & $100 \%$ \\
2 & 3 & 3 & 3 & 3 & 3 & 3 & 3 & 3 & 3 & $100 \%$ \\
3 & 3 & 3 & 3 & 3 & 3 & 3 & 3 & 3 & 3 & $100 \%$ \\
4 & 3 & 3 & 3 & 3 & 3 & 3 & 3 & 3 & 3 & $100 \%$ \\
$\begin{array}{c}\text { \% tiap } \\
\text { soal }\end{array}$ & $100 \%$ & $100 \%$ & $100 \%$ & $100 \%$ & $100 \%$ & $100 \%$ & $100 \%$ & $100 \%$ & $100 \%$ & \\
\hline
\end{tabular}

Gambaran tersebut juga terlihat pada hasil wawancara T1-004"yang diketahui sih, kita jadi ingat rumus-rumus sih, rumus persegi panjang, keliling dan luasnya”, T100-6 "Rumus-rumusnya dan bagaimana cara kita menghitung dengan benar".Dari hasil wawancara tersebut terlihat bahwa siswa T1 memahami langkah-langkah yang akan digunakan dalam menyelesaikan soal open ended. Kategori yang sama juga didapatkan oleh T2dalam memahami masalah matematika berbentuk soal open ended pada soal pertama, soal kedua termasuk kategori baik, sama halnya dengan soal yang ketiga dan keempat juga termasuk dalam kategori baik. Hasil transkrip wawancara pada siswa T1dan T2 tersebut senada dengan hasil jawaban siswa $\mathrm{T} 1$ dan $\mathrm{T} 2$ dimana mampu menyatakan apa yang diketahui dan apa yang ditanyakan.

Memperhatikan kategori yang didapatkan oleh kedua siswa kemampuan Tinggi (T1, dan T2) dalam tahap memahami masalah berdasarkan langkah-langkah tahapan polya siswa T1 dan T2 termasuk dalam kategori baik 100\%.Berdasarkan tahapan penyelesaian soal nomor 1, soal nomor 2, soal nomor 3 dan soal nomor 4 juga dikategorikan baik $100 \%$
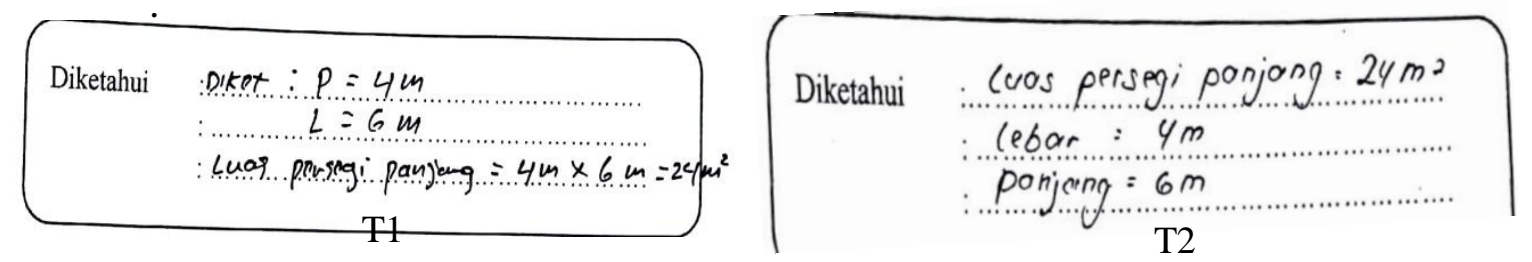
Gambar 1. Langkah-langkah T1dan T2 dalam memahami masalah
Penyelesaian Soal Open Ended

Langkah Polya Selanjutnya yaitu menyusun rencana pemecahan masalah matematika berbentuk soal open ended pada siswa berkemampuan Tinggi yaitu siswa T1 dalam menyusun rencana pemecahan masalah matematika berbentuk soal open ended pada soal pertama, soal kedua termasuk kategori baik, sama halnya dengan soal yang ketiga dan keempat juga termasuk dalam kategori baik. Kategori yang didapatkan oleh T2 dalam menyusun rencana pemecahan masalah matematika berbentuk soal open ended pada soal 
pertama, soal kedua termasuk kategori baik, sedangkansoal yang ketigadan keempat juga termasuk dalam kategori baik.Siswa T1 dan T2 dapat menyusun rencana pemecahan masalah dengan baik terlihat pada gambar 8 Siswa T1 menuliskan seperti pada soal nomor 2, ditanya apa yang terjadi? Danbagaimana kelilingnya?Misal $\mathrm{p}=10 \mathrm{~cm}$, dan $\mathrm{l}=$ $10 \mathrm{~cm}$, maka $\mathrm{k}=2 \mathrm{p}+2 \mathrm{l}=40 \mathrm{~cm}$.

Hal tersebut senada dengan hasil transkrip wawancara T1-018"Pertama kita tulis yang diketahui, terus yang kedua ditanya, terus yang ketiga dijawab.Terus kita sesuaikan dengan soalnya dan rumus-rumusnya".Hasil Transkrip wawancara T2-018 "Yang diketahui itu kan luas, keliling, lebar dan panjang. Terus yang ditanyakan itu kan keliling dan luasnya. Ada juga soal yang nomor 4 ditanyakan panjang dan lebarnya dan kelilingnya sudah diketahui", T2-024 "Dibaca soalnya dulu, terus dipahami, habis itu dibawahnya kita pake 3D.Diketahui, Ditanya, Dijawab. Jadi kita harus betul memami soalnya".

Hasil transkrip wawancara pada siswa T1 dan T2 tersebut senada dengan hasil jawaban siswa T1 dan T2 dimana siswa kategori kemampuan tinggi dapat menyusun rencana pemecahan masalah dengan baik dan rencana tersebut dapat membantunya dalam memecahkan masalah matematika berbentuk open ended dengan tepat.Memperhatikan kategori yang didapatkan oleh kedua siswa kemampuan Tinggi (T1, dan T2) dalam tahap menyusun rencana pemecahan masalah berdasarkan langkah-langkah tahapan polya siswa T1 dan T2 termasuk dalam kategori baik 100\%.Berdasarkan tahapan penyelesaian soal nomor 1, soal nomor 2, soal nomor 3 dan soal nomor 4 juga dikategorikan baik $100 \%$.

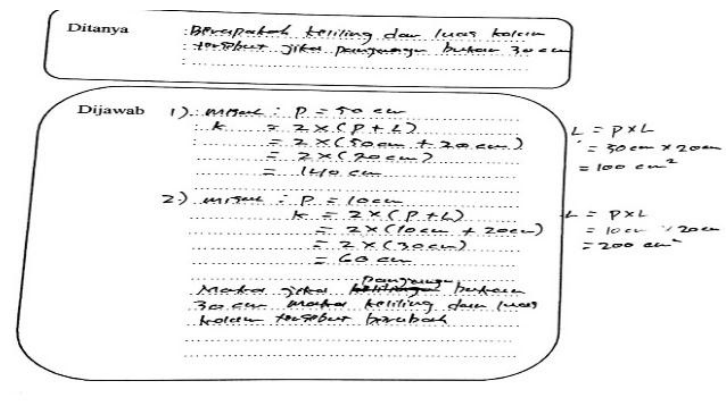

T1

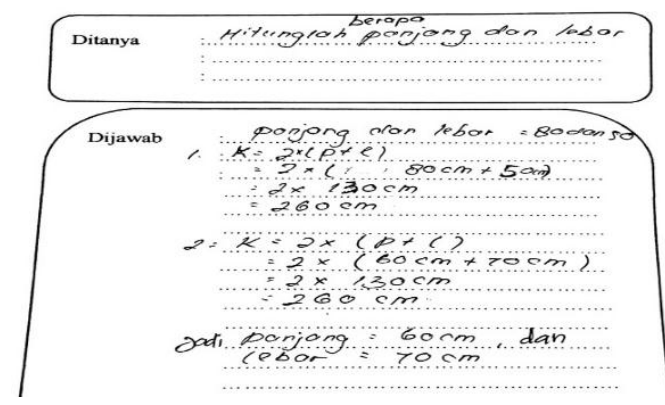

$\mathrm{T} 2$

Gambar 2. Langkah-langkah T1 dan T2 dalam menyusun dan melaksanakan
penyelesaian Soal Open Ended

a) Melaksankan Rencana Pemecahan

Langkah selanjutnya melaksanakan rencana pemecahan masalah matematika berbentuk open endedpada siswa berkemampuan tinggi T1 dan T2 dalam melaksanakan rencana pemecahan masalah matematika berbentuk soal open ended termasuk kategori baik, pada soal pertama, soal kedua, soal ketiga, dan juga soal keempat. Pada gambar 9 siswa T2 menuliskan pada soal nomor 3, cara 1: panjang kolam $=40 \mathrm{~cm}$, lebar kolam $=$ $20 \mathrm{~cm}$, maka keliling $=2 \times(p+l)=160 \mathrm{~cm}$. luas $=p \times l=40 \mathrm{~cm} \times$ $20 \mathrm{~cm}=800 \mathrm{~cm}^{2}$. Hal ini senada dengan hasil wawancara siswa T1-028 "Sudah, karena menurut $k u$ sih, kalo sudah pake rumus ya sudah pasti benar.Karena ilmu matematika adalah ilmu pasti. T2-034“ ya, mungkin benar, karena sudah sesuai dengan langkah-langkah yang saya ketahui. Berdasarkan tahapan penyelesaian soal nomor 1, soal nomor 2, soal nomor 3 dan soal nomor 4 juga dikategorikan baik 100\%. 
b) Mengecek Kembali

Langkah terakhir Polya yaitu mengecek kembalisiswa T1 dan T2 dapat mengungkapkan alasan untuk setiap langkah penyelesaian yang ditempuh dan memberikan kesimpulan pada akhir jawaban dengan benarmaka siswa T1 dan T2 termasuk dalam kategori baik $100 \%$ berdasarkan tahapan polya, dan berdasarkan tahap memeriksa kembali pada soal nomor 1 , soal nomor 2, soal nomor 3 dan soal nomor 4 . Hal tersebut juga senada dengan hasil transkipwawancara T1-031"sudah dong", danT1-033 "dihitunglagi pake rumusrumusnya".Hasil transkrip wawancara T2-033 "benar", dan T2-035 "dihitunglagi pake rumus-rumusnya".

\section{1) Siswa Berkemampuan Sedang}

Siswa berkemampuan Sedang dalam penelitian ini diperoleh, berdasarkan nilai yang mengacu pada hasil tes kemampuan matematika yang memperoleh nilai $(60<x \leq$ 80).Berikut ini adalahproses penyelesaian soal opend ended dengan menggunakan langkah Polya pada siswa yang berkemampuan sedang.

Tabel 5. Deskripsi langkah siswa berkemampuan sedang berdasarkan langkah Polya

\begin{tabular}{cccccccccccc}
\hline \multirow{2}{*}{$\begin{array}{c}\text { Langkah } \\
\text { Polya }\end{array}$} & $\mathbf{1}$ & $\mathbf{2}$ & $\mathbf{S I}$ & $\mathbf{3}$ & $\mathbf{4}$ & $\mathbf{1}$ & $\mathbf{2}$ & $\mathbf{3}$ & $\mathbf{4}$ & $\begin{array}{c}\text { Skor } \\
\text { Polya }\end{array}$ & $\begin{array}{c}\text { \% } \\
\text { tahapan }\end{array}$ \\
& & & & & & & & & & & \\
1 & 3 & 3 & 3 & 3 & 2 & 1 & 1 & 2 & 2,25 & $75 \%$ \\
2 & 3 & 1 & 1 & 3 & 1 & 1 & 1 & 1 & 1,5 & $50 \%$ \\
3 & 3 & 1 & 1 & 3 & 2 & 1 & 1 & 1 & 1,6 & $54,2 \%$ \\
4 & 1 & 1 & 1 & 1 & 1 & 1 & 1 & 1 & 1 & $33,3 \%$ \\
$\begin{array}{c}\text { \% tiap } \\
\text { soal }\end{array}$ & $83,3 \%$ & $50 \%$ & $50 \%$ & $83,3 \%$ & $50 \%$ & $33,3 \%$ & $33,3 \%$ & $41,7 \%$ & $53 \%$ & \\
\hline
\end{tabular}

a) Memahami Masalah

Berdasarkan hasil tabel diatas menunjukan proses penyelesaian masalah matematika berbentuk open ended pada siswa berkemampuan Sedang yaitu siswa S1 dalam memahami masalah matematika berbentuk soal open ended pada soal pertama, soal kedua, soal ketiga dan soal keempat termasuk dalam kategori baik 100\%. Dikategorikan baik karena siswa S1 dapat menyebutkan dengan baik informasi yang ada pada soal dan dapat menyebutkan apa yang diketahui, ditanya dalam soal open ended berbasis problem solving.Pada gambar 10, seperti pada soal nomor 1 siswa S1 dapat memahami soal dengan menuliskan luas sebuah persegi panjang, panjang $4 \mathrm{~m}$, dan lebar $6 \mathrm{~m}$ sehingga luasnya menjadi $24 \mathrm{~m}^{2}$.Gambaran tersebut juga terlihat pada transkrip hasil wawancara S1-004“disini disuruh cari luasnya, disuruh caranya berbeda dengan soalnya”.

Kategori yang didapatkan olehS2 dalam memahami masalah matematika berbentuk soal open ended pada soal pertamakategori cukup, soal kedua, soal ketiga termasuk dalam kategori kurang,dan soal keempat termasuk dalam kategori cukup $50 \%$. Dikategorikan cukup karena siswa S2 cukup dapat menyebutkan informasi yang ada pada soal dan cukup dapat menyebutkan apa yang diketahui, ditanya dalam soal open ended berbasis problem solving.Pada gambar11, seperti pada soal nomor 4 siswa S2 menuliskan keliling $=260 \mathrm{~cm}$. Gambaran tersebut juga terlihat pada siswa yang kurang yakin terhadap jawabannya sendiri terlihat pada hasil wawancara S2-006 "Mencari panjangnya, dan luasnya,eh.... Keliling, mencari luas yang ditanya pada soal”. 
Hasil transkrip wawancara siswa S1 dan S2 senada dengan hasil jawaban S1 dan S2 dimana siswa S1 mampu menyatakan apa yang diketahui dan ditanyakan pada soal, sedangkan untuk siswa S2 dikategorikan kurangkarena siswa S2 dapat menyebutkan salah satu informasi dengan benar yang ada pada soal seperti diketahui atau ditanya dalam soal open ended berbasis problem solving. Memperhatikan kategori yang didapatkan oleh siswa S1 dan S2, kategori kelompok siswa kemampuan sedang dalam memahami masalah dikategorikan baik $75 \%$.

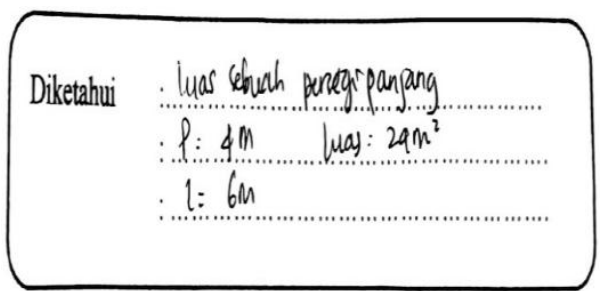

S1

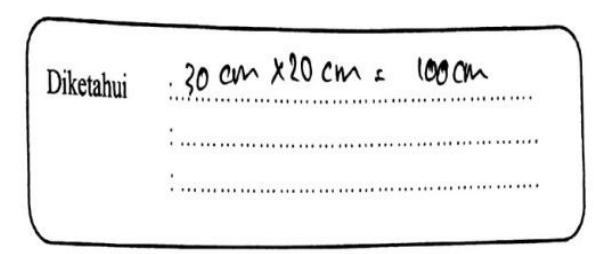

S2

\section{Gambar 3. Langkah-langkah S1 dalam memahami masalah Penyelesaian Soal Open Ended}

b) Menyusun

Menyusun rencana pemecahan masalah matematika berbentuk soal open ended pada siswa berkemampuan Sedang yaitu siswa S1 dalam menyusun rencana pemecahan masalah matematika berbentuk soal open ended pada soal pertama, termasuk kategori baik, sedangkan untuk soal kedua, dan untuk soal ketiga termasuk dalam kategori kurang, karena siswa S1 Siswa tidak dapat menentukan langkah-langkah penyelesaian untuk menjawab soal open ended.Gambar 12 siswa S1 menuliskan seperti pada soal nomor 2, ditanya bagaimana jika panjangnya bukan $20 \mathrm{~m}$, apa yang terjadi? Dan bagaimana kelilingnya? Misal jika panjang persegi panjang $=4$ maka keliling persegi panjang $=24 \mathrm{~cm} \times 10 \mathrm{~cm}=240 \mathrm{~cm}$. Hasil jawaban S1 terlihat jelas bahwa siswa S1 kurang mampu menyusun rencana, karena rumus keliling persegi panjang itu $2 \times(p+l)$ bukan $p \times l$. Soal keempat termasuk dalam kategori baik. Dikatakan baik karena siswa S1 mampu menuliskan rumus sebelum mengerjakan soal yang ditanyakan.

Kategori yang didapatkan oleh S2 dalam menyusun rencana pemecahan masalah matematika berbentuk soal open ended pada soal pertama, soal kedua, soal ketiga, dan soal keempat dikategorikan kurang, karena siswa S2 dapat menentukan langkah-langkah penyelesaian untuk menjawab soal open ended.Gambar 13 siswa S2 menuliskan seperti pada soal nomor 3, ditanya berapa keliling dan luas kolam tersebut jika panjangnya bukan 30 $\mathrm{cm}$ ?misalnya panjangnya misal $1,(60 \mathrm{~cm} \times 20 \mathrm{~cm}=1200 \mathrm{~cm})$. Misal 2, $(30 \mathrm{~cm} \times$ $2 \mathrm{~cm}=60 \mathrm{~cm}^{2}$ ). Hasil jawaban S2 juga terlihat jelas bahwa siswa S2 kurang mampu menyusun rencana pemecahan masalah, karena rumus keliling persegi panjang itu $2 \times(p+$ l) bukan $p \times l$.

Hasil transkrip wawancara pada siswa S1 dan S2 senada dengan hasil jawaban siswa S1 dan S2, dimana siswa kategori kemampuan sedang S1 apabila dilihat berdasarkan tabel 19 dilampiran halaman 123, dikategorikan cukup 66,7\%. Siswa kategori kemampuan sedang S2 dikategorikan kurang 33,3\%. Memperhatikan kategori yang didapatkan oleh siswa S1 dan S2, kategori kelompok siswa kemampuan sedang dalam menyusun rencana pemecahan masalah dikategorikan cukup 50\%. 
c) Melaksankan Rencana Pemecahan

Langkah selanjutnya yaitu melaksanakan rencana pemecahan masalah matematika berbentuk open endedpada siswa berkemampuan sedang S1 pada soal pertama termasuk kategori baik dan soal kedua, soal ketiga termasuk dalam kategori kurang senada dengan hasil transkrip wawancara S1-032 "belum sedikit, karena ada soalnya yang membuat saya bingung. Soal keempat termasuk dalam kategori baik. Dikategorikan baik karena siswa dapat menyelesaikan soal sesuai langkah-langkah penyelesaian secara runtut dan menentukan hasil akhir dengan benar, terlihat pada gambar 13 siswa S2 menuliskan pada soal nomor 1, ditanya bagaimana jika lebar sebuah persegi panjang bukan $4 \mathrm{~m}$ apa yang terjadi? Dan bagaimana dengan luasnya? Rumus $=p \times l$. Cara 1 , misalnya jika panjangnya $7 \mathrm{~m}$, maka jadinya panjang $\times$ lebar $=7 \mathrm{~m} \times 6 \mathrm{~m}=42 \mathrm{~m}^{2}$.

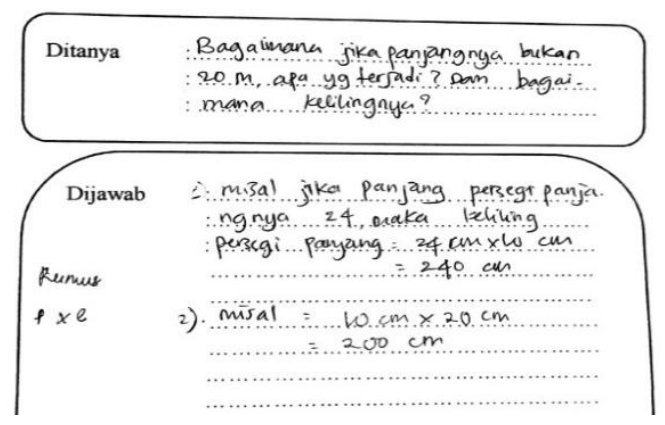

S1

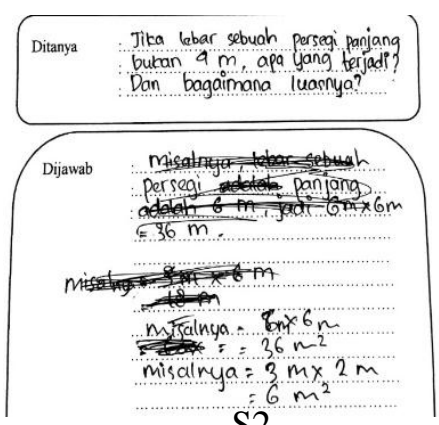

S2

Gambar 4. Langkah-langkah S1 dan S2 dalam menyusun dan merencanakan masalah Penyelesaian Soal Open Ended

d) Mengecek Kembali

Langkah mengecek kembali pada kelompok siswa kemampuan sedang termasuk kategori kurang 33,3\%. Dari kedua siswa tersebut terlihat pada kedua siswa 2 tersebut tidak melakukan pengecekkan kembali.

\section{Kesimpulan dan Saran}

Hasil analisis data penelitian mengenai kemampuan pemecahan masalah matematika pada siswa kelas VII SMP Muhammadiyah Aimas dalam menyelesaikan soal pemecahan masalah dapat disimpulkan berdasarkan empat langkah-langkah pemecahan masalah Polya yaitu: 1) Tahap memahami masalah berdasarkan langkah polya untukkategori kelomopok kemampuan Tinggi $(\mathrm{T} 1, \mathrm{~T} 2)$ termasuk kategori baik 100\%, kategori kelompok kemampuan Sedang (S1, S2) termasuk kategori baik 75\%, dan kelompok kemampuan Rendah (R1, R2) juga termasuk dalam kategori baik 75\%. 2) Tahap menyusun rencana pemecahan masalah berdasarkan langkah polya untuk kategori kelomopok kemampuan Tinggi $(\mathrm{T} 1, \mathrm{~T} 2)$ termasuk kategori baik 100\%, kategori kelompok kemampuan Sedang (S1, S2) termasuk kategori cukup 50\%, dan kelompok kemampuan Rendah (R1, R2) juga termasuk dalam kategori cukup 58,3\%. 3) Tahap melaksanakan rencana pemecahan masalah berdasarkan langkah polya untuk kategori kelomopok kemampuan Tinggi $(\mathrm{T} 1, \mathrm{~T} 2)$ termasuk kategori baik $100 \%$, kategori kelompok kemampuan Sedang (S1, S2) termasuk kategori cukup 54,2\%, dan kelompok kemampuan Rendah (R1, R2) juga termasuk dalam kategori cukup 58,3\%. 4) Tahap terakhir langkah polya yaitu mengecek kembali. Kategori kelomopok kemampuan Tinggi (T1,T2) dalam mengecek kembali termasuk kategori baik 100\%, kategori kelompok kemampuan Sedang (S1, S2) termasuk kategori kurang 33,3\%, dan kelompok kemampuan Rendah (R1, R2) juga termasuk dalam kategori kurang 33,3\%. 


\section{Daftar Pustaka}

Foong, Pui Yee. (2009). Mathematical Problem Solving. Di unduh secara online pada tanggal 20 januari 2018 di http://books.google.co.id/books?id=RnD2 QYymMcC\&printsec $=$ frontcover $\& \mathrm{hl}=\mathrm{id} \# \mathrm{v}=$ onepage $\& \mathrm{q} \& \mathrm{f}=$ false.

Kemendikbud. 2016. Peringkat dan Capaian PISA Indonesia Mengalami Peningkatan. Di unduh secara online pada tanggal 25 Juli 2019 di https://www.kemdikbud.go.id/main/blog/2016/12/peringkat-dan-capaian-pisaindonesia-mengalami-peningkatan

Mustikasari. (2010). Pengembangan Soal-Soal Open Ended pokok bahasan bilangan pecahan di sekolah menengah pertama, artikel dalam Jurnal Pendidikan Matematika, Vol. 4(1), edisi Juli, pp. 45-53. Palembang: Universitas Sriwijaya.

OECD. (2015) Problem Solving Colaborative Framework. https://www.oecd.org/pisa/pisaproducts/Draft\%20PISA\%202015\%20Collaborativ\%2 OProblem\%20Solving\%20Framework\%20.pdf.Diakses tanggal 01 February 2018

Sukayasa, 2012. Pengembangan Model Pembelajaran Berbasis Fase-Fase Polya untuk Meningkatkan Komunikasi Penalaran Siswa SMP dalam Memecahkan Masalah Matematika, (Online). Vol 01, no.01, Diakses pada 26 Januari 2018).

Sutrisno, et al. (2013). Profil kemampuan mahasiswa pendidikan matematika Ikip PGRI Semarang dalam memecahkan masalah open ended pada mata kuliah kalkulus 1 Berdasarkan Tingkat Kemampuan Mahasiswa. Semarang: IKIP PGRI Semarang.

Widjajanti, D. B. (2009). Kemampuan pemecahan Masalah Matematis Mahasiswa Calon Guru Matematika: Apa dan Bagaimana Mangembangkannya. Makalah disampaikan pada Seminar Nasional Matematika dan Pendidikan Matematika Jurusan Pendidikan Matematika FMIPA UNY 5 Desember 2009. 